\title{
Consideration of Uncertainty and Multiple Disciplines in the Determination of Sustainable Criteria for Rural Roads Using Neutrosophic Logic
}

\author{
Leonardo Sierra ${ }^{1, *(1)}$, Felipe Araya ${ }^{2}\left(\mathbb{D}\right.$ and Víctor Yepes ${ }^{3(\mathbb{C}}$ \\ 1 Departamento de Obras Civiles, Universidad de La Frontera, Temuco 4811230, Chile \\ 2 Departamento de Obras Civiles, Universidad Técnica Federico Santa María, Valparaíso 2390123, Chile; \\ felipe.araya@usm.cl \\ 3 Institute of Concrete Science and Technology (ICITECH), Universitat Politècnica de València, \\ 46022 Valencia, Spain; vyepesp@cst.upv.es \\ * Correspondence: leonardo.sierra@ufrontera.cl
}

check for

updates

Citation: Sierra, L.; Araya, F.; Yepes, V. Consideration of Uncertainty and Multiple Disciplines in the

Determination of Sustainable Criteria for Rural Roads Using Neutrosophic Logic. Sustainability 2021, 13, 9854. https://doi.org/10.3390/su13179854

Academic Editors: Maria

Socorro Garcia Cascales and

Francisco Ortega-Fernandez

Received: 2 August 2021

Accepted: 31 August 2021

Published: 2 September 2021

Publisher's Note: MDPI stays neutral with regard to jurisdictional claims in published maps and institutional affiliations.

Copyright: (c) 2021 by the authors. Licensee MDPI, Basel, Switzerland. This article is an open access article distributed under the terms and conditions of the Creative Commons Attribution (CC BY) license (https:/ / creativecommons.org/licenses/by/ $4.0 /)$.

\begin{abstract}
In Latin America, there is a wide gap between kilometers of paved ways and those with no type of protection. This situation is worse in rural areas, limiting development opportunities and inhabitants' quality of life. In Chile, there are state programs that seek to reduce the territorial gap through basic low-cost paving solutions; however, the prioritization criteria for rural roads are unclear. Multiple actors affect the rural territories, and the non-existence of reference patterns increases subjectivity in infrastructure decision making. This study attempts to determine criteria that influence the selection of rural roads in southern Chile to promote sustainable territorial development considering multiple actors and the uncertainty of the selection process. For this, a documentary review, field visits, and 12 semi-structured interviews were conducted. The criteria are validated through a multidisciplinary panel of experts and the application of neutrosophic numbers to address the uncertainty derived from the expert consultations. The results of this study contribute 14 sustainable criteria in order to support the planning of basic rural roads in southern Chile.
\end{abstract}

Keywords: rural road; uncertainty; Chile; neutrosophic; sustainability; stakeholders

\section{Introduction}

The improvement of rural roads gives rural areas access to other services and contributes decent mobility. Suitable planning reduces inequality in the provision and quality of infrastructure services, particularly for reducing poverty and isolation in rural and indigenous contexts [1]. This approach is consistent with the aim of sustainable development, which promotes the improvement of conditions of equality in the access to infrastructure and services to reduce multidimensional poverty. In this context, planning for territorial development can be understood as the set of conditions for making a regional or local unit and promoting the respect and the exercise of the right of components of territorial diversity [2]. In this sense, territorial planning is an instrument for achieving sustainable development in a territory guided by the principles of environmental sustainability, equity, social and territorial cohesion, and democratic governance [2,3].

Indeed, in Latin America, there are still dilapidated rural roads with deep slopes and unstable soil that prevent adequate motorized transport. This is inconsistent with the strategic needs of production, connectivity, and territorial development. In this context, $88.7 \%$ of exports travel by rural roads and allow the distribution of goods and services to the entire territory. There are more than 900 million inhabitants in rural areas who do not have a suitable system of transport, which exacerbates isolation and poverty [1,3]. Against this background, it is normal for rural connectivity to run through muddy roads when it rains or through excessive dust when it is dry. Thus, rural infrastructure offers opportunities to 
generate a productive transformation and sustainable territorial development, addressing the particular conditions of the setting. The lack or inequality of infrastructure quality places an obstacle to rural development in deprived areas.

In 2015, the road infrastructure in Latin America and the Caribbean reached $3 \mathrm{~km}$ of paved road for every $100 \mathrm{~km}^{2}$ of territorial area [1]. Given the limited availability of public resources, the most critical mobility needs must be identified for a gradual development of the region. In this sense, investment in rural connectivity can be seen as a sequential, long-term process $[4,5]$. This approach avoids the risk of investing prematurely in more expensive, bloated, or inappropriate long-term works.

In Chile, the road network in 2019 covered $85,926 \mathrm{~km}$, of which $56 \%$ were gravel and earth, and more than 52\% were rural [6]. In 2003, the Basic Roads Program was created to find a progressive solution. A basic road consists of a wearing structure with no stabilizing protection or geometric change. It has the particular feature of mean daily traffic in the year of less than 300, with no more than 75 heavy vehicles per day [7]. The Basic Roads Program is meant to improve the quality of life of the inhabitants of rural environments, to reduce the costs of conservation and modifications of granular materials, and to improve the users' transportation comfort. In 2019, the Basic Roads Program offered a solution for $30,000 \mathrm{~km}$ of the national network $[1,6]$.

However, the investment allocation for this infrastructure cannot be assessed on an equal footing under the parameters of national public investment systems based on socioeconomic benefit and demand. The low occupancy rate of these infrastructures limits their evaluation and, in fact, the time savings tend to lose meaning in the rural context without the assessment of the social and economic interactions [8,9]. For these purposes, in Chile, these programs are funded directly with public works conservation sector budgets. Thus, even the criteria and methods used to assess the investment and prioritization of the Basic Roads Program are not clearly defined [10]. This condition is not very different from what occurs in other Latin American countries, where low-demand infrastructure support programs become special glossa of the national budget [1,11-13].

The focus of rural basic road investment is not limited to maximizing the benefit, but the creation of territorial capacities, where there are none or where they are very precarious [4]. The creation of capacities improves the bond between urban and rural, which acts as a catalyst for the productive improvements and income in a rural territory. For this, the evaluation method that best fits in these cases requires consideration of not only socioeconomic, but also social, environmental and technical aspects related to a territory [14].

In Chile, most of the time, when conducting a viability study for an infrastructure project, in practice, it is evaluated and prioritized according to the economic aspect $[7,15]$. Nowadays, infrastructure is not just a means for a territory's economic development, but is also related to direct aspects, such as access to education, health, work, elements of culture or identity, and pollution of the environment, as well as indirect and cross-sectional ones, such as equality. Road infrastructure is no exception; nor are, in particular, those of a low standard that promote development in vulnerable areas. Therefore, an adequate assessment of rural infrastructure projects must consider the incidence of the many aspects that affect territorial development. Planned rural connectivity interventions that include the organization of the context and its needs normally result in new transport services with predictable itineraries at reasonable prices for population groups that are not considered in the current mobility system [8,12].

In this vein, they emphasize the implementation of two infrastructure planning model proposals for rural roads that consider non-economic variables. The United Nations (UN) has proposed the rural access index (RAI), which represents the percentage of the population that lives within $2 \mathrm{~km}$ of a road. This indicator is consistent with the aim of equitable sustainable development in access to infrastructure; however, measuring the population in this situation is not currently implemented in the census programs of Latin American and Caribbean countries [16]. On the other hand, in the province of Corrientes, Argentina, the 
social, productive, and educational have been determined, in addition to resilience and adaptation, as key approaches to prioritizing the rural infrastructure investment in the road network under a geographic information system $[17,18]$. However, multidisciplinary participation and the approaches of different actors in territorial development (farmers, users, resident ethnic groups, tourist operators, and regional governments, among others) have scarcely been documented in decision-making models. In addition, participation processes reveal uncertainties in value judgments regarding the incidence in a specific territory or a certain period, which has yet to be sufficiently considered.

Indeed, the infrastructure planning of rural transport must be coordinated with other complementary policies to synchronize the different impacts according to ethnic groups, genders, ages, and other areas of population characterization [9,19]. In addition, to satisfy the demand for mobility, it is necessary to design inter-territorial joining; i.e., the means of connectivity affect the particular organization of the territory [1]. This shows that a road planning model requires multidisciplinary participation and knowledge of the context in order to demonstrate the effects on the territory and to adequately represent the influences of the road network. The heterogeneity of regional development and the impossibility of standardizing an impact in different contexts are relativized aspects in the decision models [20].

In a territorial system, multiple actors and disciplinary areas that can recognize the needs of a geographic space participate, each based on training and a biased approach. Nevertheless, the integration and interactions of the actors in a territory compel integral recognition as part of a holistic approach [14]. This situation implies a multidisciplinary approach and, as a result, it increases the uncertainty of the value judgments of the assessment criteria of an infrastructure that influences a territory [21-23]. The integration of a specialized disciplinary group can reduce knowledge uncertainty; however, the variability of the participation method, multidisciplinary integration, and the inexistence of patterns of reference for non-mastered disciplines can even lead to an indetermination and inconsistency, which must be taken into consideration. In this vein, the neutrosophic numbers are a way of processing cognitive information in decision-making problems with multiple criteria. This technique derives from the fuzzy set theory and works with incomplete data to capture a value judgment with degrees of indetermination, truth, and falsehood [24]. The Neutrosophic Numbers theory has been used to solve decision-making problems related to the location of waste incineration plants [25], the selection of energy technology [26], and the assessment of the sustainability of concrete bridges [21].

Accordingly, the improvement of rural roads is a contribution to productivity and territorial development, yet its prioritization criteria are not adjusted to the national system of conventional investments. In addition, an evaluation model that represents the influence of rural roads on the territory must include multiple criteria and consider the multiple actors and disciplines. This implies the determination of a holistic decision-making model that must include the uncertainty in value judgements about the territorial system. In fact, there is no model for prioritizing the basic rural roads in Chile that includes sustainable territorial development criteria. All of the above leads us to ask the following questions: What are the representative criteria of the territory for evaluating the improvement of basic rural roads? How are these criteria determined with a multidisciplinary participation approach and uncertainty? Therefore, this work proposes a method of generating assessment criteria for basic rural roads that promote the sustainable planning of a territory through multidisciplinary participation and the consideration of uncertainty using neutrosophic logic. This article is based on the case study of the roads concentrated in the region of $\mathrm{La}$ Araucanía, Chile.

The following section presents the main theoretical underpinnings of the techniques used in the paper, the research method, and the background of the case study. Later, the partial and final results are exposed. Finally, the conclusions are presented. 


\section{Materials and Methods}

In this section, we explain the rationale for the methods used to achieve the objectives of this study-namely, the primary techniques, the research process, and the case study. In this way, the analytic hierarchy process (AHP) and triangular neutrosophic numbers (NNTs) were the main techniques. The context of this study is a set of 119 rural road projects in the region of La Araucania, Chile.

\subsection{Main Techniques}

The proposed method is based mainly on two techniques that capture, group, and process the uncertain cognitive information of multidisciplinary specialists: The analytic hierarchy process (AHP) and processing through neutrosophic sets.

$\mathrm{AHP}$ is an evaluation technique in which decision makers compare two elements that belong on the same hierarchical level. Each comparison is based on the fundamental scale of Saaty [22], which expresses how important an element $i$ is in terms of $j$ on a scale of 1 (equal importance) to 9 ( $i$ is extremely more important than $j$ ), and intermediate values are taken to relativize the comparison. Thus, when $n$ elements are compared among themselves, the outcome of a square comparison matrix is made up of values $\left\{a_{i j}\right\}$ and their reciprocals $\left\{a_{j i}=1 / a_{i j}\right\}$, and when $i=j$, the value of $a_{j i}=1$, with $i, j \in\{1, . ., n\}$. For more information on the foundations and implementation of the AHP technique, see Saaty [22].

As an extension of the AHP method, to consider the vagueness of the judgments issued, triangular neutrosophic numbers (TNNs) are used. Neutrosophic numbers are derives from fuzzy logic theory and are expressed as $\bar{a}=\langle[a 1, a 2, a 3] ; t \bar{a}, i \bar{a}, f \bar{a}\rangle$. A TNN is made up of a triangular distribution $[a 1, a 2, a 3]$ that represents the lowest valuation limit, the most likely value, and the highest valuation limit, respectively, according to the fundamental scale of Saaty. In addition, $t \bar{a}, i \bar{a}, f \bar{a}$ are associated with the values that determine the maximum degree of truth, the minimum of indetermination, and falsehood, respectively, coming from the characterization of the individuals consulted. The reciprocal of a TNN is associated with a value $\frac{1}{\bar{a}}=\left\langle\left[\frac{1}{a^{3}}, \frac{1}{a 2}, \frac{1}{a 1}\right] ; t \bar{a}, i \bar{a}, f \bar{a}\right\rangle$, and the diagonal comparison between the same element is represented as $a_{i i}=\langle[1,1,1] ; 0,0,0\rangle$. Other properties and operativity of the neutrosophic sets can be found in [27] and [28].

Specifically, this study seeks to determine the weights of importance that a set of specialists assigns to certain assessment criteria for basic rural roads, thus addressing the individual and collective uncertainty. For this, and in line with the guidelines of [21], the representative implementation of neutrosophic numbers requires the development of three phases, which are represented in Figure 1. In the first stage, AHP matrices from each expert and the matrices with a degree of certainty with respect to each comparison are determined. The expert profile analysis is characterized on the basis of the credibility, indetermination, and inconsistency of their responses [22-24]. These processes transform the conventional AHP matrix into TNNs [29] and determine the weights [30]. In the second phase, the relevance that each expert presents is determined according to their characterization [31] in order to group the neutrosophic weights. Finally, in the third phase, the neutrosophic numbers that were added are fuzzified [32] and defuzzified [33] to be constituted in crisp weights by each item that is evaluated.

\subsection{Research Method}

The implementation of this method is meant to identify the selection criteria for the improvement of basic rural roads in order to promote sustainable territorial development. Figure 2 represents the work process, which is grouped into two stages. The first stage is an exploration of the assessment criteria of basic rural roads that influence the sustainability of a territory. The results of this stage bring about a preliminary conceptualization of the influence of basic roads on territorial sustainability that is reflected through a preliminary set of assessment criteria. In the second stage, the criteria are subjected to a validation process through the opinions of a set of multidisciplinary specialists and the consideration of the uncertainty in their value judgments. The results of the second stage are weights 
that the set of specialists gives to the assessment criteria, and thus, the selection of those with the greatest contributions to the sustainability of the territory is agreed upon.

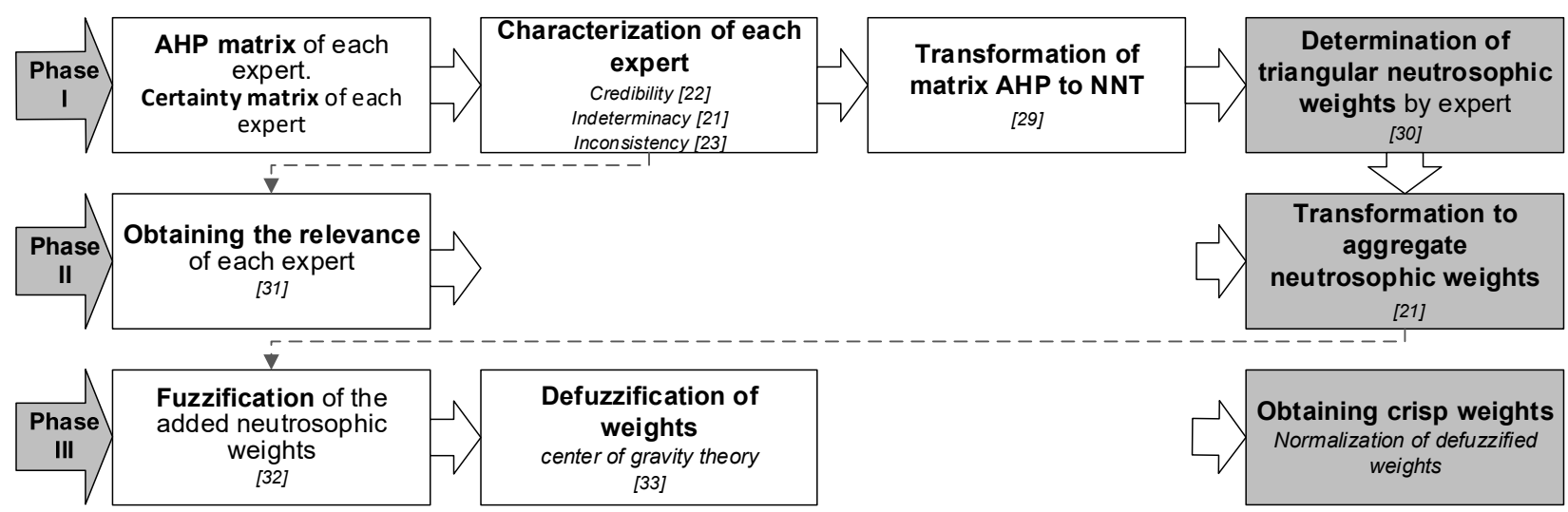

Figure 1. Phases of application of the neutrosophic numbers (adapted from [21]).

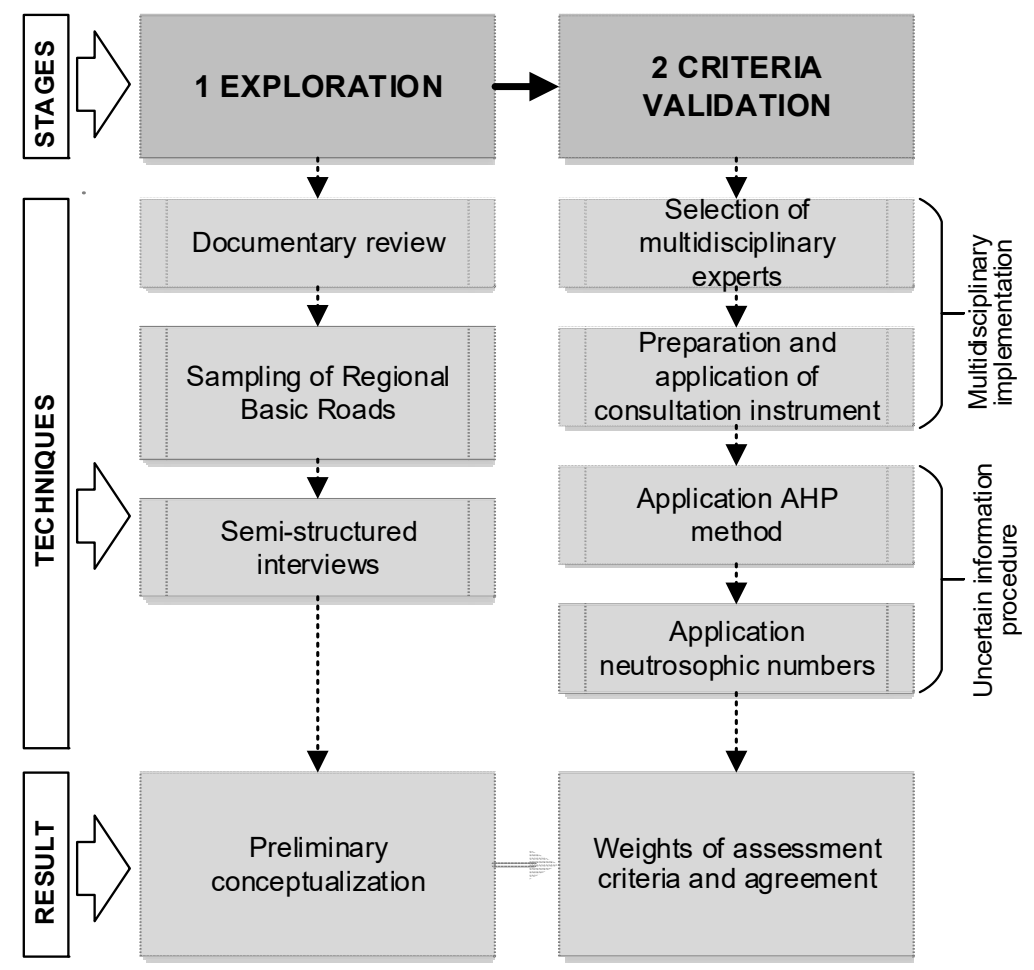

Figure 2. Research method.

In the exploration stage, a triangulation of the information is required. In principle, a review of the scientific literature and technical documents is performed. The literature review here addressed 45 works that included articles indexed in the WOS between 2010 and 2020 and technical documents from the Inter-American Development Bank (IADB), Economic Commission for Latin America and the Caribbean (ECLAC), and national institutions (Table 1). In addition, a stratified sampling of the improved rural basic roads was performed by regional development area. Road selection was prioritized according to the greatest regional accessibility [34]. The selected roads were studied by reviewing their technical history (profile, blueprint, project, environmental impact study) and through field visits. These data were contrasted with the results of twelve semi-structured interviews with sector specialists representing the Highway Administration of the Ministry of Public Works, the Offices of Social Work and Development from eight communes, Regional De- 
velopment and Habitat NGOs, university academics (geography, civil works, economics), and local leaders from rural areas. The selection of the interviewees was based on their availability, experience (more than 6 years), and performance in a representative position of an institution or group of interest for the study. The interviews were conducted between July and December 2019 and were applied in person or over video conference/telephone (during the COVID-19 pandemic). Each interview was recorded and transcribed to apply a content analysis [35].

Table 1. Review of the scientific-technical literature.

\begin{tabular}{cc} 
Area of Study & Authors \\
\hline $\begin{array}{c}\text { Social: Citizen participation, Identity, Mobility, Education, Health, Isolation, } \\
\text { Integration, Risks for the user, Beneficiary population, Public transport, Historical and } \\
\text { cultural sites, Habitat fragmentation, Poverty and income, Security of the } \\
\text { surroundings. }\end{array}$ & {$[4,9,10,15,19,22,36-52]$} \\
Technical: Road safety, Material acquisition, Geometry of the route, Existing \\
infrastructure, Deterioration, Risk of disaster (flooding, earthquake), Innovation, \\
Traffic flow, Soil movements, Hydrology. \\
Economic: Economic area activity, Use of public resources, Maintenance costs, \\
$\begin{array}{r}\text { Community economic development, Externality and cost analysis, Employment, } \\
\text { Tourist areas, Investment cost. }\end{array}$ \\
$\begin{array}{r}\text { Environmental: Landscape, Protected species, Protected areas, Health risks in the } \\
\text { context, Green infrastructure, Recycled materials, Efficient use of water and energy } \\
\text { resources, Reduction of emissions. }\end{array}$ \\
{$[9,11,15,21,39-41,44,55-58,60,61,64-74]$} \\
\hline
\end{tabular}

In the validation stage, a set of 24 experts with different disciplines and training participated in the resolution of a pairwise ranking questionnaire of the preliminary criteria from stage 1. The selection criteria of the experts followed the directions of [80] and previous implementations by the research team [22]; the protected profile criteria of the experts who participated in the study were: having a recognized prestige/trajectory for their knowledge in relation to basic roads or territorial development, being a resident of the Region of La Araucanía, Chile, having a higher technical or professional degree, having a minimum experience of three years, being available and willing to participate in the study, and belonging to and representing the institutions/actors considered to be of interest for territorial development. Table 2 identifies the representation, training, and experience of the group of 24 experts who participated in the study.

Table 2. Profiles of the experts.

\begin{tabular}{|c|c|c|c|c|c|}
\hline Institutional Representation & $\%$ & Education & $\%$ & $\begin{array}{c}\text { Years of } \\
\text { Experience }\end{array}$ & $\%$ \\
\hline $\begin{array}{c}\text { Regional Government of } \\
\text { Araucanía }\end{array}$ & 13 & Civil Engineering & 17 & 5 to 10 & 22 \\
\hline $\begin{array}{l}\text { Ministry of Public } \\
\text { Works-Araucanía }\end{array}$ & 17 & Geography & 9 & 11 to 15 & 26 \\
\hline $\begin{array}{c}\text { Agriculture and Livestock } \\
\text { Service }\end{array}$ & 9 & Agronomy/Forestry & 17 & 16 to 20 & 30 \\
\hline Regional universities [4] & 26 & Public administration & 4 & more than 20 & 22 \\
\hline Regional NGOs [2] & 9 & Sociology & 12 & & \\
\hline $\begin{array}{c}\text { Regional oversight } \\
\text { committees (neighbors) }\end{array}$ & 13 & Construction & 17 & & \\
\hline Municipal departments & 13 & $\begin{array}{c}\text { Pedagogy } \\
\text { Business Administration } \\
\text { Social services } \\
\text { Environmental Sciences }\end{array}$ & $\begin{array}{c}4 \\
4 \\
4 \\
12\end{array}$ & & \\
\hline
\end{tabular}


The consultation instrument was based on a pairwise ranking matrix of the preliminary criteria in which the experts were asked to provide a value for the importance according to the Saaty scale from 1 to 9 . Figure 3 shows the consultation instrument applied in this study for four categories of criteria: social, environmental, technical, and economic. In addition, in a second instance and through a copy of the same instrument, the experts were asked to identify their degree of certainty about the valuations assigned in each ranking. For this, they were asked to assess the degree of certainty on a scale from 0 (total ignorance) to $100 \%$ (complete certainty). The consultation instrument and the preliminary criteria included were verified and feedback was provided by 5 experts prior to its application. From this point, the AHP method and the TNNs were applied according to the theories specified in point 2.1 of this section and the procedure shown in Figure 1.

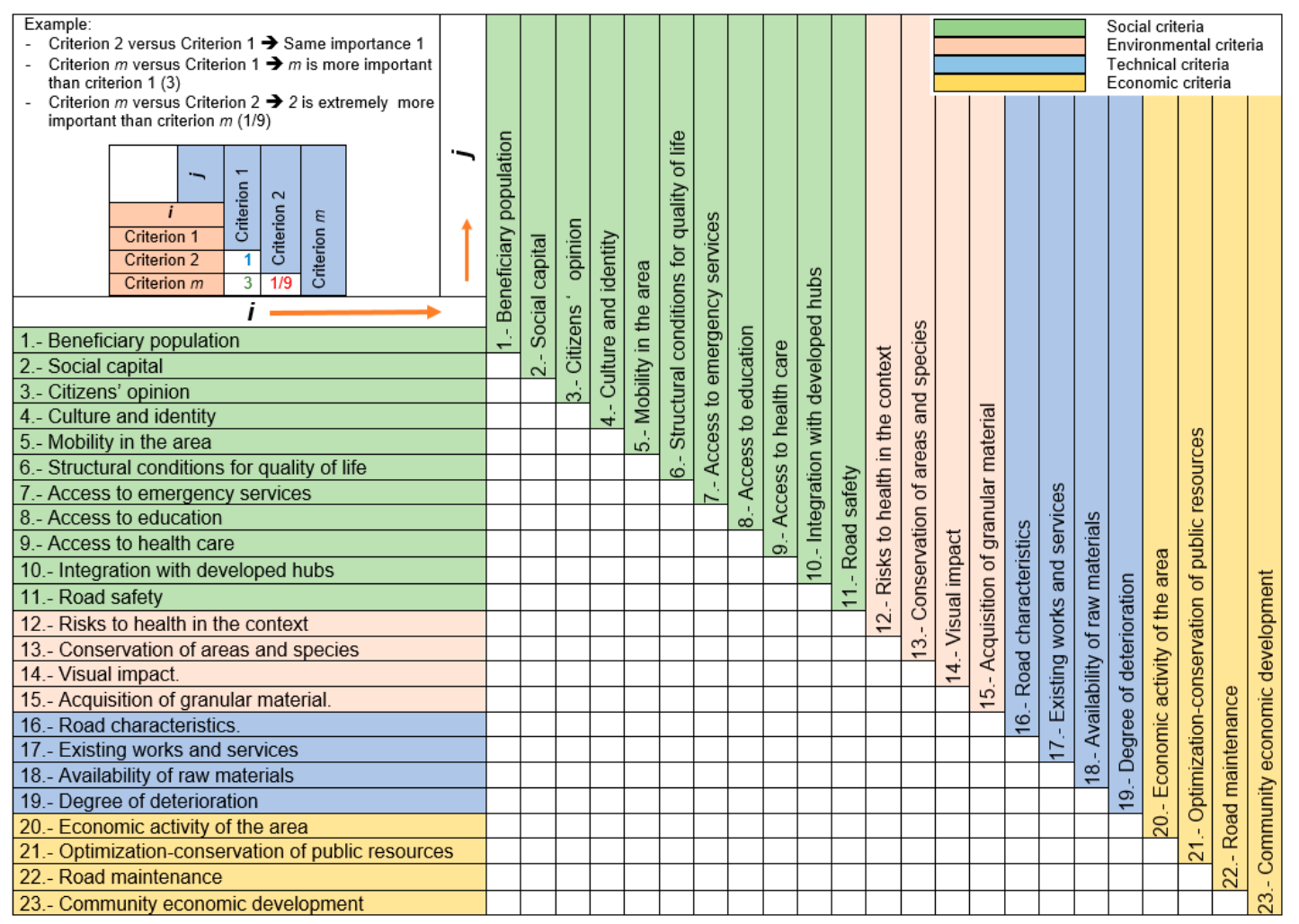

Figure 3. Extract of the AHP and certainty consultation instruments.

\subsection{Case Study}

The proposed method was applied to a set of basic roads in the region of La Araucanía, Chile. The region of La Araucanía has a surface area of 31,842 km2, 32 communes, and a rural population of 281,127 people (32.3\% regional population). In 2019 , the region's road network was $14 \%$ of the national network, and of that, $77 \%(9314 \mathrm{~km})$ were roads that had a gravel or dirt course. This represented the greatest length of unpaved road in the nation [6]. In a universe of 119 projects for basic regional roads executed between 2003 and 2017, a probability sample of 83 projects $(976 \mathrm{~km}$ ) was determined at a $95 \%$ confidence level [81]. The sample of roads was distributed in eight territorial development areas for the region. Figure 4 shows the geographic location of the region, the development areas, and sample of basic roads studied. The study was conducted in the period between July 2019 and December 2020. 

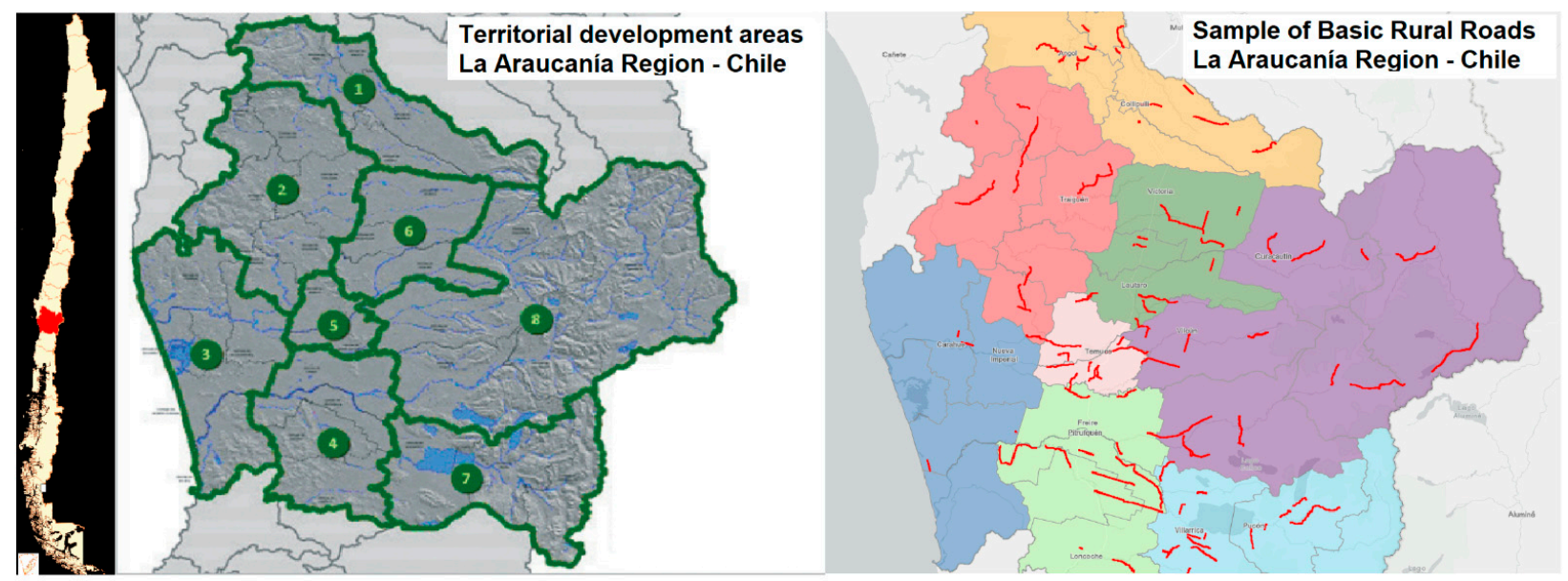

1. North Malleco; 2. Nahulebuta; 3. Intercultural of rivers and sea; 4. Cautín-Sur Association; 5. Temuco-Padre Las Casas; 6. Central Valley Association; 7. Lake Araucanía; 8. Andean mountain range.

Figure 4. Location of the case study.

\section{Results}

As a result of Stage 1, a set of 23 assessment criteria for basic rural roads emerged, which determined the sustainable contributions to territorial development in the region of La Araucanía, Chile (Figure 3). The criteria were subjected to the judgement of the experts in Stage 2 through the procedures, references, and techniques described in Sections 2.1 and 2.2.

Specifically, from the responses to the consultation instruments, the AHP matrices and those of the certainty of the 24 experts were completed.

The expert characterization was performed based on their credibility, indetermination, and inconsistency. Credibility was determined according to each expert's level of experience and knowledge [22]. Indetermination was determined on the basis of the average of the levels of certainty expressed by the expert [21]. According to Saaty [23], inconsistency is determined through the consistency ratio for a ranking of 23 elements and an established inconsistency ratio limit. The integration of these elements determines the relevance of an expert in the consultation process [31]. Table 3 provides the characterization of the 23 experts participating in the study.

According to this, in addition to the triangular variations of the Saaty scale associated with levels of certainty [29] and the determination of the weights [30], the transformation into a weight matrix in TNNs was possible. Table 4 shows the triangular neutrosophic weights obtained for expert 1, in which the first three columns represent the triangular distribution and the last three represent the degrees of truth, indetermination, and falsehood.

According to the guidelines by Navarro et al. [21], the TNN weights of each expert could be added by criterion according to the weighted average with respect to the relevance of each expert (Table 3). Table 5 contains the neutrosophic weights added for each criterion subjected to the experts' opinions.

According to phase III of Figure 1, the deneutrosophic representation of the added weights required fuzzification and defuzzification [32,33], which considered the uncertainty associated with the treatment of each criterion. Figure 5 shows the membership grades of the fuzzified social criteria of the greatest influence. In this case, the ordinate $\eta[x]$ represents a certainty level that determines the ambiguity of the weight (in the abscissae) of the criteria. This level of certainty is consistent with findings in other studies in which multiple experts participated in the decision making $[21,25,26]$. 
Table 3. Characterization of the experts.

\begin{tabular}{ccccc}
\hline Expert & Credibility & Indetermination & Inconsistency & Relevance \\
\hline 1 & 0.5103 & 0.3705 & 0.1600 & 0.04065 \\
2 & 0.6217 & 0.2808 & 0.0890 & 0.04621 \\
3 & 0.6359 & 0.2760 & 0.1050 & 0.04401 \\
4 & 0.6375 & 0.2092 & 0.0590 & 0.04800 \\
5 & 0.3472 & 0.5257 & 0.0820 & 0.03238 \\
6 & 0.4113 & 0.4817 & 0.0620 & 0.03434 \\
7 & 0.7530 & 0.1747 & 0.0710 & 0.05091 \\
8 & 0.4577 & 0.4017 & 0.1020 & 0.03574 \\
9 & 0.4413 & 0.4271 & 0.0610 & 0.03715 \\
10 & 0.8489 & 0.1399 & 0.1080 & 0.05138 \\
11 & 0.5761 & 0.2703 & 0.0290 & 0.04510 \\
12 & 0.3500 & 0.4905 & 0.0920 & 0.03354 \\
13 & 0.3072 & 0.4195 & 0.0530 & 0.03742 \\
14 & 0.5456 & 0.3975 & 0.1010 & 0.04064 \\
15 & 0.7621 & 0.2601 & 0.0440 & 0.04880 \\
16 & 0.6834 & 0.3220 & 0.0610 & 0.04687 \\
17 & 0.1398 & 0.3875 & 0.1340 & 0.02753 \\
18 & 0.5825 & 0.2930 & 0.1230 & 0.04366 \\
19 & 0.5161 & 0.4611 & 0.0600 & 0.03937 \\
20 & 0.7587 & 0.3261 & 0.0860 & 0.04639 \\
21 & 0.5946 & 0.2820 & 0.0610 & 0.04137 \\
22 & 0.6287 & 0.2661 & 0.0860 & 0.04212 \\
23 & 0.7265 & 0.2691 & 0.1630 & 0.04661 \\
24 & 0.5814 & 0.3538 & 0.0460 & 0.03983 \\
\hline
\end{tabular}

Table 4. Triangular neutrosophic weights for expert 1.

\begin{tabular}{|c|c|c|c|c|c|c|c|c|c|c|c|c|c|}
\hline \multicolumn{2}{|c|}{ Criterion } & \multicolumn{4}{|c|}{$\langle[a 1, a 2, a 3] ; t \bar{a}, \overline{i a}, \overline{f a}\rangle$} & \multicolumn{3}{|c|}{ Criterion } & \multicolumn{4}{|c|}{$\langle[a 1, a 2, a 3] ; t \bar{a}, i \bar{a}, \overline{f a}\rangle$} & \multirow[b]{2}{*}{0.04} \\
\hline 1 & 0.06 & 0.07 & 0.07 & 0.05 & 0.04 & 0.04 & 13 & 0.01 & 0.01 & 0.01 & 0.05 & 0.04 & \\
\hline 2 & 0.02 & 0.02 & 0.02 & 0.04 & 0.04 & 0.04 & 14 & 0.01 & 0.01 & 0.01 & 0.05 & 0.04 & 0.04 \\
\hline 3 & 0.06 & 0.07 & 0.07 & 0.05 & 0.04 & 0.04 & 15 & 0.02 & 0.02 & 0.02 & 0.04 & 0.04 & 0.04 \\
\hline 4 & 0.04 & 0.04 & 0.05 & 0.04 & 0.04 & 0.04 & 16 & 0.06 & 0.07 & 0.07 & 0.05 & 0.04 & 0.04 \\
\hline 5 & 0.06 & 0.07 & 0.07 & 0.05 & 0.04 & 0.04 & 17 & 0.01 & 0.01 & 0.01 & 0.06 & 0.04 & 0.04 \\
\hline 6 & 0.03 & 0.03 & 0.03 & 0.03 & 0.04 & 0.04 & 18 & 0.02 & 0.02 & 0.02 & 0.04 & 0.04 & 0.04 \\
\hline 7 & 0.06 & 0.07 & 0.07 & 0.05 & 0.04 & 0.04 & 19 & 0.06 & 0.07 & 0.07 & 0.05 & 0.04 & 0.04 \\
\hline 8 & 0.02 & 0.02 & 0.02 & 0.04 & 0.04 & 0.04 & 20 & 0.06 & 0.07 & 0.07 & 0.05 & 0.04 & 0.04 \\
\hline 9 & 0.06 & 0.07 & 0.07 & 0.05 & 0.04 & 0.04 & 21 & 0.01 & 0.01 & 0.01 & 0.05 & 0.04 & 0.04 \\
\hline 10 & 0.03 & 0.03 & 0.03 & 0.03 & 0.04 & 0.04 & 22 & 0.01 & 0.01 & 0.01 & 0.05 & 0.04 & 0.04 \\
\hline 11 & 0.04 & 0.04 & 0.05 & 0.04 & 0.04 & 0.04 & 23 & 0.09 & 0.11 & 0.11 & 0.05 & 0.04 & 0.04 \\
\hline 12 & 0.06 & 0.07 & 0.07 & 0.05 & 0.04 & 0.04 & - & & & & & & \\
\hline
\end{tabular}

Figure 6 represents the weights of the defuzzified and reorganized criteria from largest to smallest for each social, environmental, technical, and economic dimension. In this way and assuming the Pareto principle in each dimension, the selected criteria that contributed $80 \%$ of importance in the territorial development in each dimension were determined, and these are shown to the left of the blue arrow. For this case, the criteria with the greatest weights were social and economic, and they contributed $60 \%$ of the overall importance to territorial development. In particular, of the selected criteria, seven are social, three were economic, and two were environmental and technical in each case. 
Table 5. Added triangular neutrosophic weights.

\begin{tabular}{ccccccc}
\hline Criterion & Lowest & Middle & Highest & Truth & Indetermination & Falsehood \\
\hline 1 & 0.039 & 0.067 & 0.073 & 0.044 & 0.043 & 0.043 \\
2 & 0.030 & 0.038 & 0.065 & 0.043 & 0.043 & 0.043 \\
3 & 0.036 & 0.041 & 0.045 & 0.042 & 0.043 & 0.043 \\
4 & 0.037 & 0.046 & 0.057 & 0.042 & 0.043 & 0.043 \\
5 & 0.043 & 0.071 & 0.077 & 0.044 & 0.043 & 0.043 \\
6 & 0.028 & 0.033 & 0.069 & 0.044 & 0.043 & 0.043 \\
7 & 0.039 & 0.067 & 0.073 & 0.045 & 0.043 & 0.043 \\
8 & 0.026 & 0.032 & 0.058 & 0.044 & 0.043 & 0.043 \\
9 & 0.050 & 0.078 & 0.090 & 0.047 & 0.043 & 0.043 \\
10 & 0.023 & 0.034 & 0.060 & 0.041 & 0.043 & 0.043 \\
11 & 0.041 & 0.051 & 0.060 & 0.043 & 0.043 & 0.043 \\
12 & 0.034 & 0.040 & 0.050 & 0.043 & 0.043 & 0.043 \\
13 & 0.017 & 0.020 & 0.046 & 0.046 & 0.043 & 0.043 \\
14 & 0.016 & 0.022 & 0.058 & 0.045 & 0.043 & 0.043 \\
15 & 0.018 & 0.020 & 0.046 & 0.044 & 0.043 & 0.043 \\
16 & 0.026 & 0.037 & 0.042 & 0.043 & 0.043 & 0.043 \\
17 & 0.032 & 0.036 & 0.041 & 0.042 & 0.043 & 0.043 \\
18 & 0.009 & 0.019 & 0.026 & 0.044 & 0.043 & 0.043 \\
19 & 0.026 & 0.030 & 0.056 & 0.043 & 0.043 & 0.043 \\
20 & 0.043 & 0.054 & 0.061 & 0.042 & 0.043 & 0.043 \\
21 & 0.018 & 0.046 & 0.052 & 0.043 & 0.043 & 0.043 \\
22 & 0.023 & 0.051 & 0.058 & 0.043 & 0.043 & 0.043 \\
23 & 0.038 & 0.066 & 0.072 & 0.044 & 0.043 & 0.043 \\
\hline
\end{tabular}

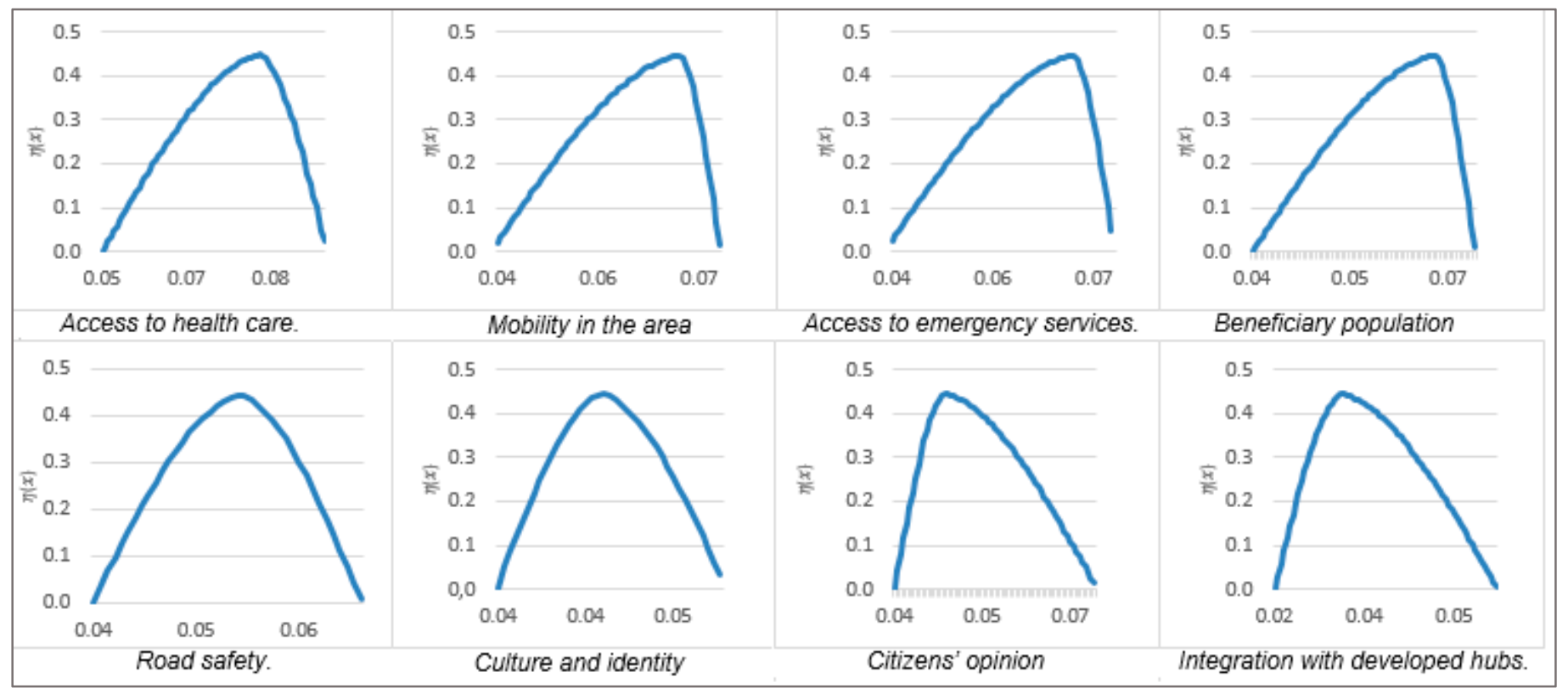

Figure 5. Membership ratings of the social criteria of greatest influence. 


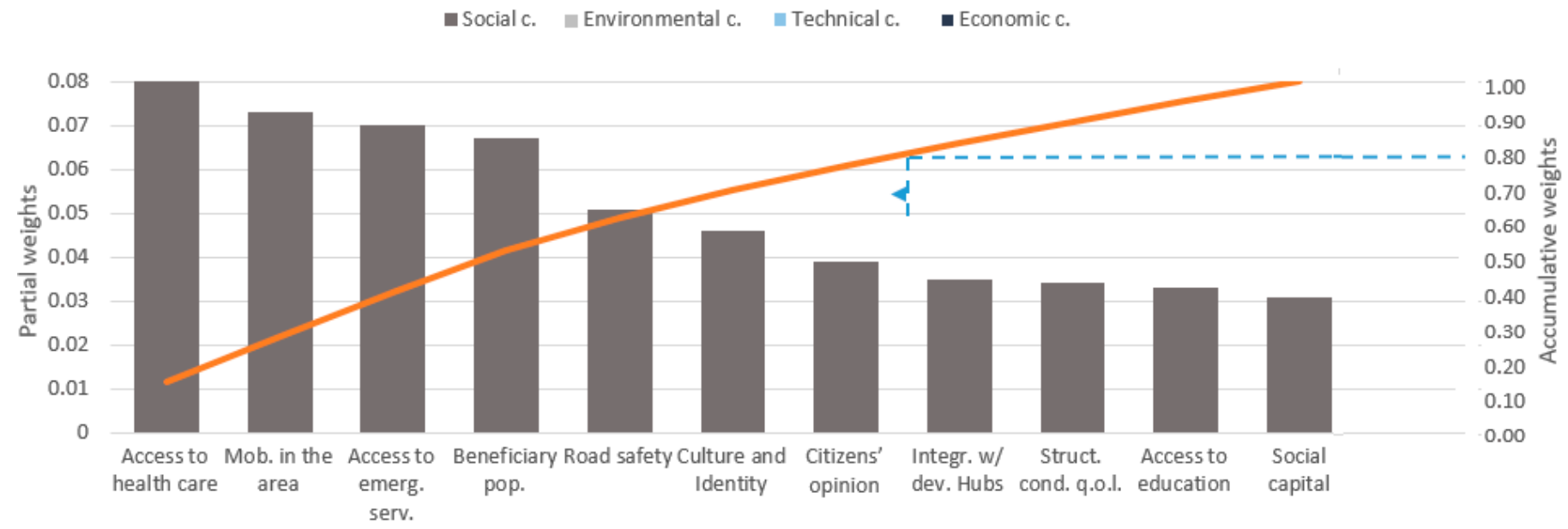

Assessment criteria

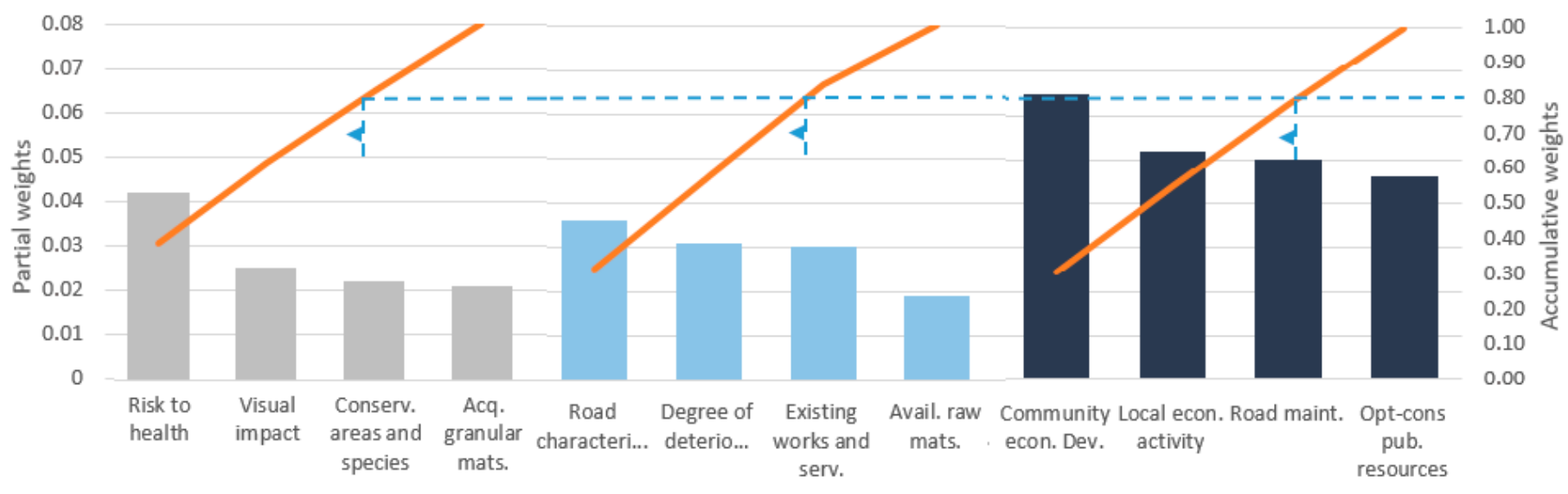

Assessment criteria

Figure 6. Selection of important criteria.

Consistently with these results, the contextual considerations determined the importance of certain criteria. The region of La Araucanía has a strong Mapuche indigenous influence, and this culture is predominant in the rural sectors. In addition, it is one of the regions in the country with the most rural roads, the smallest bridges, and with a temperate humid and rainy climate [6]. The situation is worse in mountainous areas in the winter, making land access with developed hubs impossible. The greatest provision and diversity of regional services are located in only three of the 32 regional communes. In the rural sectors of the country, travel by land is the main access for private communication, public transport, and freight. These conditions explain the social and economic development needed (selected in Figure 6), which determined $60 \%$ of the importance. The region also exceeds the average kilometers of road present in each region by $123 \%$, and the allocation of resources is centralized nationally. Therefore, there is a need for resources for the conservation and paving of regional roads. This constrains the prioritization of roads according to their geometric characteristics and deterioration as a result of tight budgets. In general terms, the experts argued that the rural contributions of basic roads for the case study were derived from the opportunity for better accessibility and for the reduction of inequalities in opportunities between rural areas and the country's urban centers.

\section{Conclusions}

This study determined a set of fourteen assessment criteria for basic rural roads that affect sustainable territorial development in the region of La Araucanía in Chile. For this, a method was proposed that included an exploration stage and a validation stage using 24 multidisciplinary experts. The processing of the value judgments of each expert consid- 
ered uncertainty by applying an analytic hierarchy process and the neutrosophic numbers theory. According to the literature, this process reveals a level of acceptable ambiguity for a participatory set of multidisciplinary experts.

Through the deneutrosophic representation of the weights and the Pareto principle, seven social criteria were selected, which included: access to health, mobility in the area, access to emergency services, beneficiary population, road safety, culture and identity, and citizens' opinion. Three economic criteria were selected: community economic development, local economic activity, and road maintenance. Two environmental criteria were selected: local health risks and visual impact. Finally, two technical criteria were selected: characteristics of the route of the road and the degree of deterioration.

According to the results, the experts considered that $60 \%$ of the influence on the rural development in the territory of La Araucanía was given by social and economic criteria related to the adequate selection of the improvement of basic roads.

The validity of these results is limited to the geographic context of analysis (La Araucania, Chile) and the national and regional perception of the citizenry between 2019 and 2020. Future studies can address the dynamic perception after the capture of longitudinal data to determine long-term strategies. Complementary studies based on the selected criteria, indicators, and databases for prioritizing rural roads can be undertaken as a tool for sustainable territorial development.

This study proposes a method that systematizes the uncertainty inherent in multidisciplinary experts in order to support decision making about investment in road infrastructure. Likewise, this proposal complements a transparent agreement process between different sectors with incomplete information. This would support the fluidity of public participation processes, which are often slow, difficult to objectify, and easily politically manipulated. In this case, a list of assessment criteria can be used by public agencies for the selection of improvements of basic roads and territorial planning in the region, which includes rural sectors that are not always considered.

Author Contributions: Conceptualization, L.S. and F.A.; methodology L.S. and V.Y.; validation, L.S. and F.A.; formal analysis, L.S.; investigation, L.S. and V.Y.; data curation, L.S.; writing-original draft preparation, L.S.; writing—-review and editing L.S., F.A., and V.Y.; All authors have read and agreed to the published version of the manuscript.

Funding: This research was funded by Agencia Nacional de Investigación y Desarrollo (ANID) of the Government of Chile under the Fondo Nacional de Desarrollo Científico y Tecnológico (FONDECYT-INI), grant number 11190501; and by the Spanish Ministry of Science and Innovation through the FEDER Funding under Project PID2020-117056RB-I00.

Institutional Review Board Statement: The study was conducted according to the guidelines of the Declaration of Helsinki and approved by the Ethics Committee of the University of La Frontera (Protocol 094/19 approved October 09 ${ }^{\text {th }}, 2019$ ).

Informed Consent Statement: Informed consent was obtained from all subjects involved in the study.

Data Availability Statement: Data are available under request to the corresponding author.

Acknowledgments: The authors acknowledgethe Road Administration (MOP), Agricultural and Livestock Service (SAG), IDER-UFRO, Regional Government, Municipalities and neighborhood leaders of the Region of La Araucania, Chile for their support. In addition, this study was possible through the collaboration of the GIPS research group of the Civil Engineering Department of the University of La Frontera.

Conflicts of Interest: The authors declare no conflict of interest.

\section{References}

1. Economic Commission for Latin America and the Caribbean. Rural Roads: Key Roads for the Productivity and Con-Nectivity and the Development. Available online: https://www.cepal.org/es/publicaciones/45781-caminos-rurales-vias-claves-laproduccion-la-conectividad-desarrollo-territorial (accessed on 21 March 2021). 
2. Economic Commission for Latin America and the Caribbean. Planificación Para el Desarrollo Territorial Sostenible (LC/CRP.17/3). Santiago de Chile, Chile. 2019. Available online: https://www.cepal.org/es/publicaciones/44731-planificacion-desarrolloterritorial-sostenible-america-latina-caribe (accessed on 20 August 2021).

3. Pelaez Ponce, A.V.; Pastor Vargas, C.; Gonzalez Rios, C.; Saavedra, E.; Castillo, F.C.; Evia Vizcarra, J.L.; Sour, L.; Mesalles Jorba, L.; Gonzalez, M.; Neri, M.; et al. Inversión en Infraestructura Pública y Reducción de la Pobreza en América Latina. Rio de Janeiro, Brasil. 2011. Available online: https:/ / www.kas.de/c/document_library/get_file?uuid=42349fcb-6292-d816-6965-41fb4a979 a53\&groupId=252038 (accessed on 1 December 2020).

4. Gannon, C.; Lui, Z. Transporte: Infraestructura y Servicios; The World Bank: Washington, DC, USA, 2001.

5. Technical Committee A.4 Rural Road Systems and Accessibility to Rural Areas. Best Practices for the Sustainable Maintenance of Rural Roads in Developing Countries; World Road Association: Paris, France, 2013. Available online: https: / / www.piarc.org/en/order-library / 19078-en-Best \%20practices $\% 20$ for $\% 20$ the $\% 20$ sustainable $\% 20$ maintenance $\% 20$ of $\% 20$ rural\%20roads\%20in\%20developing\%20countries (accessed on 1 March 2020).

6. Dirección de Vialidad- Ministerio de Obras Públicas Chile. Red Vial Nacional: Dimensionamientos y Características. Reporte Técnico de la Subdirección de Desarrollo. Santiago de Chile, Chile. 2020. Available online: http://www.vialidad.cl/ areasdevialidad/gestionvial/Paginas/Informesyestudios.aspx (accessed on 1 March 2021).

7. Herrera, M.; Fuenzalida, C.; Tudela, A. Informe final de Evaluación del programa de Caminos Básicos. Reporte de la Direccion de Vialidad Chile. Santiago de Chile, Chile. 2009. Available online: https://www.dipres.gob.cl/597/articles-141136_informe_final. pdf (accessed on 1 December 2020).

8. Smith, M.; Gonzalez, S. Evaluación de caminos rurales: Hacia un enfoque orientado al usuario. Rev. de Urban. 2000, 2,1-15. [CrossRef]

9. Van de Walle, D. Impact evaluation of rural road projects. J. Dev. Eff. 2009, 1, 15-36. [CrossRef]

10. Contraloría General de la República de Chile. Auditoría de los Procesos Para la Conservación de Caminos, Informe Final N 501 de 03 Diciembre de 2018. Santiago de Chile, Chile. 2018. Available online: https:/ / www.contraloria.cl/web/cgr/informes-deauditorias (accessed on 1 December 2020).

11. Inter-American Development Bank. Infraestructura Vial y Bienestar Económico: Evaluación de un Programa de Caminos Rurales en la República Dominicana; Informe Técnico OVE/TDP-01/06; Oficina de Evaluación y Supervisión; Republica Dominicana: Santo Domingo, Dominican Republic, 2006.

12. Sierra, L.A.; Pellicer, E.; Yepes, V. Method for estimating the social sustainability of infrastructure projects. Environ. Impact Assess. Rev. 2017, 65, 41-53. [CrossRef]

13. Secretaria de Comunicación y Trasporte de México. Caminos Rurales. 2019. Available online: https://www.gob.mx/ caminosrurales (accessed on 30 March 2021).

14. Shen, L.; Lu, W.; Peng, Y.; Jiang, S. Critical Assessment Indicators for Measuring Benefits of Rural Infrastructure Investment in China. J. Infrastruct. Syst. 2011, 17, 176-183. [CrossRef]

15. Paredes, G.; Herrera, R. Teaching Multi-Criteria Decision Making Based on Sustainability Factors Applied to Road Projects. Sustainability 2020, 12, 8930. [CrossRef]

16. World Bank. World-Measuring Rural Access; Update 2017/18 (English); World Bank Group: Washington, DC, USA, 2019; Available online: http:/ / documents.worldbank.org/curated/en/543621569435525309/World-Measuring-Rural-Access-Update-2017-18 (accessed on 30 March 2021).

17. Revista Vial. Metodología Para Priorizar una Red Vial de Caminos Rurales-Primera Parte, 130, diciembre. Available online: http:/ / revistavial.com/metodologia-para-priorizar-una-red-vial-de-caminos-rurales/ (accessed on 30 March 2021).

18. Revista Vial. Metodología Para Priorizar una Red Vial de Caminos Rurales—Segunda Parte, 131, Diciembre. Available online: http:/ / revistavial.com/metodologia-para-priorizar-una-red-vial-de-caminos-rurales-2/ (accessed on 30 March 2021).

19. Sierra, L.A.; Yepes, V.; García-Segura, T.; Pellicer, E. Bayesian network method for decision-making about the social sustainability of infrastructure projects. J. Clean. Prod. 2018, 176, 521-534. [CrossRef]

20. Esteves, A.M.; Franks, D.; Vanclay, F. Social impact assessment: The state of the art. Impact Assess. Proj. Apprais. 2012, 30, 34-42. [CrossRef]

21. Navarro, I.; Yepes, V.; Martí, J.V. Sustainability assessment of concrete bridge deck designs in coastal environments using neutrosophic criteria weights. Struct. Infrastruct. Eng. 2019, 16, 949-967. [CrossRef]

22. Sierra, L.A.; Pellicer, E.; Yepes, V. Social Sustainability in the Lifecycle of Chilean Public Infrastructure. J. Constr. Eng. Manag. 2016, 142, 05015020. [CrossRef]

23. Beynon, M.J. Analytic Hierarchy Process. In The SAGE Dictionary of Qualitative Management Research; Moutinho, L., Hutcheson, G., Eds.; SAGE Publications Ltd.: Thousand Oaks, CA, USA, 2011; Volume 1, pp. 9-12. [CrossRef]

24. Smarandache, F. A Unifying Field in Logics; Neutrosophy: Neutrosophic Probability, Set and Logic, 6th ed.; American Research Press: Rehoboth, NM, USA, 2007.

25. Zavadskas, E.K.; Baušys, R.; Lazauskas, M. Sustainable assessment of alternative sites for the construction of a waste incineration plant by applying WASPAS method with single-valued neutrosophic set. Sustainability 2015, 7, 15923-15936. [CrossRef]

26. Pamučar, D.; Badi, I.; Sanja, K.; Obradović, R. A Novel Approach for the Selection of Power-Generation Technology Using a Linguistic Neutrosophic CODAS Method: A Case Study in Libya. Energies 2018, 11, 2489. [CrossRef] 
27. Ye, J. Multicriteria decision-making method using the correlation coefficient under single-valued neutrosophic environment. Int. J. Gen. Syst. 2013, 42, 386-394. [CrossRef]

28. Liang, R.-X.; Wang, J.-Q.; Zhang, H.-Y. A multi-criteria decision-making method based on single-valued trapezoidal neutrosophic preference relations with complete weight information. Neural Comput. Appl. 2018, 30, 3383-3398. [CrossRef]

29. García-Segura, T.; Penadés-Plà, V.; Yepes, V. Sustainable bridge design by metamodel-assisted multi-objective optimization and decision-making under uncertainty. J. Clean. Prod. 2018, 202, 904-915. [CrossRef]

30. Enea, M.; Piazza, T. Project Selection by Constrained Fuzzy AHP. Fuzzy Optim. Decis. Mak. 2004, 3, 39-62. [CrossRef]

31. Biswas, P.; Pramanik, S.; Giri, B.C. TOPSIS method for multi-attribute group decision-making under single-valued neutrosophic environment. Neural Comput. Appl. 2015, 27, 727-737. [CrossRef]

32. Sodenkamp, M.A.; Tavana, M.; Di Caprio, D. An aggregation method for solving group multi-criteria decision-making problems with single-valued neutrosophic sets. Appl. Soft Comput. 2018, 71, 715-727. [CrossRef]

33. Chu, T.-C.; Tsao, C.-T. Ranking fuzzy numbers with an area between the centroid point and original point. Comput. Math. Appl. 2002, 43, 111-117. [CrossRef]

34. Lopez, E.; Monzón, A.; Ortega, E.; Quintana, S.M. Assessment of cross-border spillover effects of national transport infrastructure plans: An accessibility approach. Transp. Rev. 2009, 29, 515-536. [CrossRef]

35. Sierra, L.A.; Yepes, V.; Pellicer, E. A review of multi-criteria assessment of the social sustainability of infrastructures. J. Clean. Prod. 2018, 187, 496-513. [CrossRef]

36. Zulaica, L.; Celemín, J.P. Análisis territorial de las condiciones de habitabilidad en el periurbano de la ciudad de Mar del Plata (Argentina), a partir de la construcción de un índice y de la aplicación de métodos de asociación espacial. Rev. Geogr. Norte Grande 2008, 41, 129-146. [CrossRef]

37. Poch, M.A.; Carvajal, L.G.; Osorio, R.A. Metodología de Identificación de localidades en condición de aislamiento. Un caso de integración de potencialidades de SIG libres y privativos. In Proceedings of the IV Jornadas de Latinoamérica y el Caribe de gvSIG, Cre-Ciendo en Comunidad, Montevideo, Uruguay, 24-26 September 2012; Available online: http:/ / www.subdere.gov.cl/ sites/default/files/documentos/zonas_aisladas2.pdf (accessed on 15 February 2021).

38. Jeong, J.S.; García-Moruno, L.; Blanco, J.H. Un modelo web para la asistencia en la toma de decisiones en la integración de las construcciones rurales mediante planificación espacial multi-criterio. Informes de la Construcción 2014, 66, e004. [CrossRef]

39. Bueno, P.; Vassallo, J.M.; Cheung, K. Sustainability Assessment of Transport Infrastructure Projects: A Review of Existing Tools and Methods. Transp. Rev. 2015, 35, 622-649. [CrossRef]

40. Suprayoga, G.B.; Bakker, M.; Witte, P.; Spit, T. A systematic review of indicators to assess the sustainability of road infrastructure projects. Eur. Transp. Res. Rev. 2020, 12, 1-15. [CrossRef]

41. Watkins, G.G.; Mueller, S.-U.; Ramirez, M.C.; Meller, H.; Blatsos, I.; De Oliveira, J.C.F.; Casado, C.C.; Georgoulias, A.; Georgoulias, N.; Rodriguez, J. Lessons from Four Decades of Infrastructure Project-Related Conflicts in Latin America and the Caribbean; IDB-MG-549; Inter-American Development Bank: Washington, DC, USA, 2017; 90p. [CrossRef]

42. Department of Transportation of the United States, Invest. Available online: https:/ /www.sustainablehighways.org/ (accessed on 20 February 2021).

43. Diaz-Sarachaga, J.M.; Jato-Espino, D.; Alsulami, B.; Castro-Fresno, D. Evaluation of existing sustainable infrastructure rating systems for their application in developing countries. Ecol. Indic. 2016, 71, 491-502. [CrossRef]

44. Shen, L.; Jiang, S.; Yuan, H. Critical indicators for assessing the contribution of infrastructure projects to coordinated urban-rural development in China. Habitat Int. 2012, 36, 237-246. [CrossRef]

45. Mitchard, N.; Frost, L.C.; Harris, J.; Baldrey, S.; Ko, J. Assessing the impact of road schemes on people and communities. Proc. Inst. Civ. Eng.-Eng. Sustain. 2011, 164, 185-196. [CrossRef]

46. Bonsall, P.; Kelly, C. Road user charging and social exclusion: The impact of congestion charges on at-risk groups. Transp. Policy 2005, 12, 406-418. [CrossRef]

47. Jeon, C.M.; Amekudzi, A.A.; Guensler, R.L. Evaluating Plan Alternatives for Transportation System Sustainability: Atlanta Metropolitan Region. Int. J. Sustain. Transp. 2010, 4, 227-247. [CrossRef]

48. Yao, H.; Shen, L.; Tan, Y.; Hao, J. Simulating the impacts of policy scenarios on the sustainability performance of infrastructure projects. Autom. Constr. 2011, 20, 1060-1069. [CrossRef]

49. Curiel-Esparza, J.; Mazario-Diez, J.L.; Canto-Perello, J.; Martin-Utrillas, M. Prioritization by consensus of enhancements for sustainable mobility in urban areas. Environ. Sci. Policy 2016, 55, 248-257. [CrossRef]

50. Thomopoulos, N.; Grant-Muller, S. Incorporating equity as part of the wider impacts in transport infrastructure assessment: An application of the SUMINI approach. Transportation 2012, 40, 315-345. [CrossRef]

51. Gilmour, D.; Blackwood, D.; Banks, L.; Wilson, F. Sustainable development indicators for major infrastructure projects. Proc. Inst. Civ. Eng.-Munic. Eng. 2011, 164, 15-24. [CrossRef]

52. OSE-Observatorio de la Sostenibilidd en España. Patrimonio Natural, Cultural y Paisajistico Claves Para la Sostenibi-Lidad Territorial. Ministerio del Medio Ambiente, Medio Rural y Humano. Madrid España. 2009. Available online: http:/ /www.upv. es / contenidos/CAMUNISO/info/U0556177.pdf (accessed on 30 March 2021).

53. Ministerio de Obras Publicas, Chile. Incorporación de Criterios de Sostenibilidad en el Volumen 9 del Manual de Carreteras. Informe Tecnico BID. Santiago de Chile, Chile. 2020. 31p. Available online: https://planeamiento.mop.gob.cl/estudios/ Documents/Tercera_Mision_BID/5-Criterios_Sostenibilidad_V9MC_Arrasate.pdf (accessed on 15 March 2021). 
54. Arroyo, P.; Herrera, R.; Salazar, L.; Giménez, Z.; Martínez, J.; Calahorra, M. Un nuevo enfoque para la integración de factores ambientales, sociales y económicos para evaluar mezclas asfálticas con y sin neumáticos de desecho. Rev. Ing. Constr. 2018, 33, 301-314. [CrossRef]

55. Santos, J.; Flintsch, G.; Ferreira, A. Environmental and economic assessment of pavement construction and management practices for enhancing pavement sustainability. Resour. Conserv. Recycl. 2017, 116, 15-31. [CrossRef]

56. Brasil. Decreto-Lei n ${ }^{\circ} 227$, de 28 de Fevereiro de 1967. Dá nova redação ao Decreto-lei n ${ }^{\circ} 1.985$, de 29 de Janeiro de 1940 (Código de Minas). 1967; Brasília. Available online: http:/ /www.planalto.gov.br/ccivil_03/Decreto-Lei/Del0227.htm (accessed on 19 October 2020).

57. Chamorro, A.; Tighe, S.L. Development of a Management Framework for Rural Roads in Developing Countries. Transp. Res. Rec. J. Transp. Res. Board 2009, 2093, 99-107. [CrossRef]

58. Hayati, E.; Majnounian, B.; Abdi, E.; Sessions, J.; Makhdoum, M. An expert-based approach to forest road network planning by combining Delphi and spatial multi-criteria evaluation. Environ. Monit. Assess. 2013, 185, 1767-1776. [CrossRef]

59. Dirección de Vialidad- Ministerio de Obras Públicas Chile. Manual de carreteras Volumen 9: Estudios y Criterios Ambientales en proyectos viales. DGOP: Santiago de Chile, Chile. 2020. Available online: https://mc.mop.gob.cl/ (accessed on 30 March 2021).

60. Santos, G.; Behrendt, H.; Teytelboym, A. Part II: Policy instruments for sustainable road transport. Res. Transp. Econ. 2010, 28, 46-91. [CrossRef]

61. ISI. Rating System for Sustainable Infrastructure; Institute for Sustainable Infrastructure: Washington, DC, USA, 2015.

62. Macura, D.; Milenković, M.; Bojović, N.; Boškovic, B. A Model for Prioritization of Rail Infrastructure Projects Using ANP. Int. J. Transp. Econ. 2011, 3, 285-310.

63. Dirección de Vialidad- Ministerio de Obras Públicas Chile. Políticas de Conservación Vial: Caminos Básicos; Reporte Técnico: Santiago de Chile, Chile, 2011.

64. Kucukvar, M.; Gumus, S.; Egilmez, G.; Tatari, O. Ranking the sustainability performance of pavements: An intuitionistic fuzzy decision making method. Autom. Constr. 2014, 40, 33-43. [CrossRef]

65. Cadena, P.C.B.; Magro, J.M.V. Setting the weights of sustainability criteria for the appraisal of transport projects. Transport 2015, 30, 298-306. [CrossRef]

66. Bröcker, J.; Korzhenevych, A.; Schürmann, C. Assessing spatial equity and efficiency impacts of transport infrastructure projects. Transp. Res. Part B: Methodol. 2010, 44, 795-811. [CrossRef]

67. Reza, B.; Sadiq, R.; Hewage, K. Emergy-based life cycle assessment (Em-LCA) for sustainability appraisal of infrastructure systems: A case study on paved roads. Clean Technol. Environ. Policy 2014, 16, 251-266. [CrossRef]

68. Umer, A.; Hewage, K.; Haider, H.; Sadiq, R. Sustainability assessment of roadway projects under uncertainty using Green Proforma: An index-based approach. Int. J. Sustain. Built Environ. 2016, 5, 604-619. [CrossRef]

69. Boz, M.A.; El-Adaway, I.H. Creating a Holistic Systems Framework for Sustainability Assessment of Civil Infrastructure Projects. J. Constr. Eng. Manag. 2015, 141, 04014067. [CrossRef]

70. Ramani, T.; Zietsman, J.; Gudmundsson, H.; Hall, R.P.; Marsden, G. Framework for Sustainability Assessment by Transportation Agencies. Transp. Res. Rec. J. Transp. Res. Board 2011, 2242, 9-18. [CrossRef]

71. Ivanović, I.; Grujičić, D.; Macura, D.; Jović, J.; Bojović, N. One approach for road transport project selection. Transp. Policy 2013, 25, 22-29. [CrossRef]

72. Hameed, F.; Hancock, K. Incorporating Costs of Life-Cycle Impacts into Transportation Program Development. Transp. Res. Rec. J. Transp. Res. Board 2014, 2453, 77-83. [CrossRef]

73. Torres-Machi, C.; Nasir, F.; Achebe, J.; Saari, R.K.; Tighe, S.L. Sustainability Evaluation of Pavement Technologies through Multicriteria Decision Techniques. J. Infrastruct. Syst. 2019, 25, 04019023. [CrossRef]

74. Asomani-Boateng, R.; Fricano, R.J.; Adarkwa, F. Assessing the socio-economic impacts of rural road improvements in Ghana: A case study of Transport Sector Program Support (II). Case Stud. Transp. Policy 2015, 3, 355-366. [CrossRef]

75. Fernández-Sánchez, G.; Rodríguez-López, F. A methodology to identify sustainability indicators in construction project management-Application to infrastructure projects in Spain. Ecol. Indic. 2010, 10, 1193-1201. [CrossRef]

76. Larrea-Gallegos, G.; Vázquez-Rowe, I.; Gallice, G. Life cycle assessment of the construction of an unpaved road in an undisturbed tropical rainforest area in the vicinity of Manu National Park, Peru. Int. J. Life Cycle Assess. 2016, 22, 1109-1124. [CrossRef]

77. Lidskog, R.; Soneryd, L. Transport Infrastructure Investment and Environmental Impact Assessment in Sweden: Public Involvement or Exclusion? Environ. Plan. A Econ. Space 2000, 32, 1465-1479. [CrossRef]

78. Marzouk, M.; Abdelkader, E.M.; El-Zayat, M.; Aboushady, A. Assessing Environmental Impact Indicators in Road Construction Projects in Developing Countries. Sustainability 2017, 9, 843. [CrossRef]

79. Espinoza, J.; Medina, C.; Calabi-Floody, A.; Sánchez-Alonso, E.; Valdés, G.; Quiroz, A. Evaluation of Reductions in Fume Emissions (VOCs and SVOCs) from Warm Mix Asphalt Incorporating Natural Zeolite and Reclaimed Asphalt Pavement for Sustainable Pavements. Sustainability 2020, 12, 9546. [CrossRef]

80. Hallowell, M.R.; Gambatese, J.A. Qualitative Research: Application of the Delphi Method to CEM Research. J. Constr. Eng. Manag. 2010, 136, 99-107. [CrossRef]

81. Garza, H.T.; Coronel, J.A. Un método para la determinación del tamaño de muestra en encuestas sobre poblaciones finitas. Demogr. y Econ. 1970, 4, 121-128. [CrossRef] 